\title{
Pengaruh Pemberian Insentif, Pelatihan Kerja dan Pengendalian Intern terhadap Efektivitas Kinerja Karyawan
}

\author{
Manajemen SDM, Akuntansi Keperilakuan \\ Heni Risnawati $^{1 *}$, Sri Retnoningsih ${ }^{2}$ \\ ${ }^{1}$ Program Studi Akuntansi, Fakultas Ekonomi. Universitas Muhammadiyah Kudus. \\ ${ }^{2}$ Program Studi Akuntansi, Fakultas Ekonomi, Universitas Wahid Hasyim Semarang \\ *E-mail : henirisnawati3@gmail.com
}

\section{ABSTRACT}

The purpose of this study to determine the effect of providing incentives, job training and internal control on the employee performance of RSUD RAA Soewondo Pati Hospital. The population in this study is employees of the RSUD RAA Soewondo Pati Hospital. The number of samples used in this study is 235 medical and non medical employees. The analytical tool used by authors is multiple linear regression analysis to analyze the research data. The partial results of the first hypothesis of incentives do not significantly influence employee performance. That is because there are still some employees who are not satisfied with the system of providing incentives. The second hypothesis shows that job training does not significantly influence employee performance. This means that job training at the hospital is still less effective in improving performance. The third hypothesis shows that internal control has a significant positive effect on employee performance. Existing internal control at the hospital is going well in improving employee performance. The simultan research provides empirical evidence that the provision of incentives, job training and internal control together a significant effect on the employee performance of RSUD RAA Soewondo Pati Hospital.

Keywords: Incentive; Work Training; Internal Control; Employee Performance

\section{PENDAHULUAN}

Sumber daya manusia merupakan faktor utama dalam menjalankan perusahaan pada era globalisasi saat ini. Suatu organisasi yang bergerak dalam bidang jasa kesehatan, khususnya rumah sakit bertujuan untuk meningkatkan kesejahteraan masyarakat melalui pelayanan yang berkualitas kepada masyarakat. Upaya yang harus dilakukan agar mendorong 
sumber daya manusia yang dimiliki memberikan kontribusi secara optimal dalam mencapai tujuan yang diharapkan perusahaan adalah memberikan insentif keuangan maupun non keuangan akan memberikan motivasi positif kepada karyawan untuk meningkatkan kinerjanya (Weerasinghe, Gamini. 2017). Dengan adanya perhatian yang cukup besar terhadap pemberian insentif sebagai langkah yang efektif dalam meningkatkan kinerja karyawan (Stajkovic, 2003).

Kinerja karyawan merupakan hal yang perlu diperhatikan oleh RSUD RAA Soewondo Pati sebagai salah satu rumah sakit terbesar di Kota Pati yang berada di Jalan Dr. Soesanto No.114 Pati Jawa Tengah. RSUD RAA.Soewondo Pati yang terdiri dari bagian medis dan non medis menyediakan berbagai macam layanan medis, harus didukung dengan sumber daya manusia yang berkompeten untuk memberikan pelayanan kepada masyarakat. Sumber daya manusia yang berkualitas akan menghasilkan kinerja yang tinggi dan mendukung kualitas peningkatan program kerja yang ada di RSUD RAA Soewondo Pati.

Untuk mencapai kinerja yang berkualitas, pihak manajemen rumah sakit harus dapat mengetahui faktor apa saja yang dapat mendorong meningkatnya kinerja karyawan. Langkah awal yang harus diambil oleh RSUD RAA.Soewondo Pati, adalah memperhatikan permasalahan pemberian insentif banyak karyawan yang mengeluhkan keterlambatan dalam pemberian insentif sehingga berdampak pada menurunnya semangat kerja karyawan. Hal itu akan menurunkan produktivitas dan kualitas karyawan dalam memberikan pelayanan kepada masyarakat.

Pedoman tentang pemberian insentif dikeluarkan peraturan Bupati Pati No.74 Tahun 2018 tentang Remunerasi pada RSUD RAA. Soewondo Pati. Berdasarkan hasil evaluasi dalam pelaksanaan pemberian remunerasi pada RSUD RAA. Soewondo Pati, dipandang belum optimal dan perlu disesuaikan dengan perkembangan pada saat ini. Pemberian insentif pada RSUD RAA Soewondo Pati adalah tambahan pendapatan berbasis kinerja bagi seluruh pegawai yang dananya bersumber dari jasa pelayanan, keuntungan farmasi dan sumber penerimaan sah lainnya. Penelitian yang dilakukan oleh Al-Tamimi, Khaled (2018), hasil menunjukkan bahwa insentif berpengaruh signifikan terhadap kinerja karyawan.

Faktor lain yang mempengaruhi kinerja karyawan adalah dengan pelatihan kerja. Adanya pelaksanaan pelatihan kerja diharapkan karyawan dapat memberikan kontribusi kerja secara optimal karena dengan pelatihan akan meningkatkan kompe- 
tensi, melatih kemampuan, keterampilan dan menambah pengetahuan karyawan sehingga tercipta kinerja yang lebih efektif sesuai dengan tujuan yang diharapkan perusahaan. Pihak manejemen harus memastikan karyawan bekerja dengan kompeten secara teknis dan sosial sesuai dengan bidangnya (Haryati, Ari. R, 2019). Penelitian yang dilakukan oleh Nassazi, Aidah (2013), hasil menunjukkan bahwa pelatihan kerja berpengaruh positif signifikan terhadap kinerja karyawan.

Kinerja karyawan dapat lebih efektif apabila ada pengendalian internal dari manajemen. Pengendalian intern sangat diperlukan oleh perusahaan semakin optimal tingkat pengendalian, maka tingkat kinerja karyawan dalam perusahaan juga semakin tinggi. Untuk itu pengendalian intern yang efektif dan efisien untuk mencapai tujuan perusahaan. Hal tersebut menunjukkan bahwa pengendalian intern dalam perusahaan dapat mempengaruhi kinerja karyawan, yang dimana didalam komponen pengendalian internal mempunyai hubungan yang sangat penting sehingga perlu diperhatikan oleh perusahaan (Taradipa, 2015).

Penelitian ini membahas mengenai kebijakan pemberian insentif, pelatihan kerja dan pengendalian intern terhadap efektivitas kinerja karyawan. Tujuan penelitian memberikan masukan kepada pihak manajemen rumah sakit untuk mengetahui faktor apa saja yang dapat mempengaruhi kinerja karyawan. Kinerja merupakan hal yang sangat penting untuk kemajuan rumah sakit, sehingga dengan adanya sistem pemberian insentif, pelatihan kerja dan pengendalian intern diharapkan menejemen dapat mengevaluasi untuk menghasilkan kinerja karyawan yang berkualitas dalam memberikan pelayanan kepada masyarakat.

\section{TINJAUAN PUSTAKA}

\section{Insentif}

Insentif adalah kompensasi yang berkaitan dengan gaji dan produktivitas Insentif sebagai penghargaan dalam bentuk keuangan maupun non keuangan yang diberikan kepada karyawan yang mampu bekerja melebihi standar serta target yang telah ditentukan perusahaan (Panggabean, 2002. Adanya insentif dengan memberikan upah berdasarkan prestasi kerja, meningkatkan motivasi kerja karyawan sehingga dapat menciptakan kinerja karyawan yang berkualitas

\section{Pelatihan Kerja.}

Menurut Mondy (2008:210), pelatihan dan pengembangan (training and development) merupakan bagian terpenting dari upaya berkelanjutan untuk meningkatkan kompetensi karyawan dan kinerja organisasi. Pelatihan merupakan proses 
secara sistematis. Mengubah tingkah laku pegawai untuk mencapai tujuan organisasi. Pelatihan berkaitan dengan keahlian serta kemampuan pegawai untuk membantu pegawai dalam mencapai keahlian atau kemampuan tertentu agar berhasil dalam melaksanakan pekerjaannya. Pelatihan sebagai salah satu faktor yang membentuk kinerja seseorang.

Program pelatihan kerja dan pengembangan yang efektif bertujuan untuk meningkatkan kinerja karyawan. Pelatihan salah satu cara untuk mengatasi kesenjangan antara kinerja saat ini dan standar kinerja yang diinginkan. Pelatihan dapat diberikan melalui metode pembinaan dan pendampingan, kerja sama dan partisipasi bawahan. Pekerjaan tim ini memungkinkan karyawan untuk berpartisipasi aktif dalam pekerjaan dan menghasilkan kinerja yang lebih baik, sehingga meningkatkan kinerja organisasi (Sharma \& Taneja, 2018).

\section{Pengendalian Intern}

Kinerja karyawan dapat berjalan dengan baik apabila ada pengendalian internal dari manajemen. Pengendalian intern diperlukan dalam perusahaan agar kinerja perusahaan dapat berjalan secara efektif dan efisien dalam mencapai tujuan yang diharapkan. Pengendalian internal dapat didefinisikan sebagai proses yang dirancang dan dipengaruhi oleh pihak yang bertanggung jawab atas manajemen perusahaan, tata kelola, dan pihak lain untuk memberikan jaminan terhadap pencapaian tujuan perusahaan tentang efisiensi dan efektivitas operasi, kepatuhan dengan hukum dan peraturan yang berlaku serta keandalan pelaporan keuangan (Gamage, Hewage, \& Pathirana, 2018).

Pengendalian intern terdiri dari lima komponen-komponen, COSO meliputi: 1). Lingkungan Pengendalian yaitu menetapkan karakteristik suatu organisasi, mempengaruhi kesadaran pengendalian orang-orangnya 2). Penaksiran Risiko. Perusahaan harus dapat mengelola risiko yang akan dihadapi. 3).Informasi dan komunikasi adalah pengidentifikasian, penangkapan dan pertukaran informasi dalam suatu bentuk dan waktu yang memungkinkan orang melaksanakan tanggung jawab mereka. 4). Aktivitas Pengendalian adalah kebijakan dan prosedur yang membantu menjamin bahwa arahan manajemen dilaksanakan. 5). Pemantauan adalah proses yang menentukan kualitas kinerja pengendalian intern di setiap kegiatan operasional perusahaan.

\section{Kinerja}

Kinerja merupakan suatu pencapaian berhasil atau tidaknya tujuan organisasi yang sudah ditetapkan. Informasi me- 
ngenai kinerja organisasi, hal yang sangat penting digunakan untuk mengevaluasi apakah proses kinerja yang dilakukan organisasi sudah berjalan sesuai yang diharapkan atau belum (Mayasari Dan Rani.2017). Kinerja sendiri diklasifikasikan menjadi lima elemen: Perencanaan, pemantauan, pengembangan, penilaian, dan penghargaan. Dalam tahap perencanaan berarti menetapkan tujuan, mengembangkan strategi, pelaksanaan tugas dan cara dalam mencapai tujuan. Pemantauan berarti terus mengukur kinerja dan memberikan umpan balik yang berkelanjutan kepada karyawan dan kelompok kerja tentang kemajuan mereka dalam mencapai tujuan. Pengembangan dan penilaian adalah proses perbaikan kinerja karyawan secara terus menerus serta sebagai penilaian kinerja karyawan. Penghargaan sebagai motivasi karyawan atas kontribusi mereka dalam berkerja (Sharma \& Taneja, 2018).

\section{Pengembangan Hipotesis}

Pengaruh Insentif Terhadap Efektivitas Kinerja Karyawan.

Insentif merupakan sebagai faktor yang mendorong karyawan untuk dapat bekerja produktif dan menghasilkan kinerja yang berkualitas untuk mencapai tujuan yang telah ditetapkan. Adanya insentif akan memberikan motivasi karena peru- sahaan dapat memenuhi kebutuhan individu mereka. Hasil penelitian dari Alomari et all (2017), Menujukkan hasil bahwa pemberian insentif berpengaruh signifikan terhadap kinerja karyawan Pemberian insentif merupakan salah satu cara perusahaan dalam meningkatkan kualitas kerja invidu atau karyawan, karyawan akan memiliki motivasi kerja apabila perusahaan mampu memberikan kesejahteraan bagi karyawannya. Maka hipotesis dalam penelitian ini adalah sebagai berikut:

H1: Insentif berpengaruh signifikan terhadap efektivitas kinerja karyawan

\section{Pengaruh Pelatihan Kerja Terhadap Efektivitas Kinerja Karyawan.}

Pelatihan kerja yang efektif memberikan dampak terhadap sikap positif karyawan dalam meningkatkan kinerja. Pelatihan kerja memiliki beberapa komponen yaitu melalui program pengembangan pelatihan, pelatihan sesuai dengan kebutuhan karyawan dan desain program pelatihan dapat mendukung kinerja karyawan. Hasil penelitian dari Al-Mzary, Al-rifai dan AlMomany (2015), memberikan bukti empiris bahwa adanya pelatihan kerja yang tepat akan memberikan dampak positif terhadap kinerja karyawan serta dapat meningkatkan produktivitas dari perusahaan. Pelatihan kerja sangat penting dalam 
mempengaruhi kinerja karyawan, jika pelatihan kerja yang diterima sesuai dengan kebutuhan karyawan, maka dapat mendorong karyawan dalam meningkatkan kinerjanya. Maka hipotesis dalam penelitian ini adalah sebagai berikut:

$\mathrm{H} 2$ : Pelatihan kerja berpengaruh signifikan terhadap efektivitas kinerja karyawan.

\section{Pengaruh Sistem Pengendalian Intern Terhadap Efektivitas Kinerja Karya- wan.}

Sistem pengendalian intern sangat penting agar organisasi dapat berjalan dengan lancar. Pengendalian terhadap asset financial dan nonfinancial secara efisien serta kegiatan operasional perusahan harus dilakukan control dan pegawasan sehingga perusahaan memperoleh keuntungan. Hasil penelitian yang dilakukan oleh Olufunmilayo, A.A (2018), hasil penelitian menunjukkan bahwa sistem pengendalian intern berpengaruh positif signifikan terhadap kinerja karyawan. Maka hipotesis dalam penelitian ini adalah sebagai berikut:

H3: Pengendalian intern berpengaruh signifikan terhadap efektivitas kinerja karyawan.

Pengaruh Insentif, Pelatihan Kerja dan Pegendalian Intern Secara Simultan Berpengaruh Terhadap Kinerja Karyawa
Penelitian yang dilakukan oleh Meutia, Rahmi (2015) tentang insentif dan pelatihan kerja berpengaruh terhadap kinerja karyawan, hasil penelitian menunjukkan bahwa secara bersama-sama atau simultan insentif dan pelatihan kerja berpengaruh signifikan terhadap kinerja karyawan. Penelitian juga dilakukan oleh Hidayat, Irwana, Erry Dan Sri (2014), memberikan hasil pemberikan insentif dan pelatihan kerja berpengaruh secara simultan terhadap kinerja karyawan. Adanya insentif yang efektif dan pelatihan kerja serta pengendalian intern yang baik mendorong peningkatan kinerja karyawan. Maka hipotesis dalam penelitian ini adalah sebagai berikut:

H4: Pengaruh insentif, pelatihan kerja dan pengendalian intern secara simultan berpengaruh terhadap kinerja karyawan.

\section{METODE PENELITIAN}

Jenis penelitian ini adalah metode deskriptif dengan pendekatan kuantitatif yaitu dengan mengumpulkan dan mengolah data yang berupa angka dan menjelaskannya secara menyeluruh dan sesuai dengan pemasalahan yang akan diteliti, sehingga dalam penelitian ini akan memperoleh suatu hasil dari pengolahan data yang disebut hasil penelitian. Jenis data yang digunakan adalah data primer dengan teknik pengumpulan data menggunakan kuesioner melalui google form yang diba- 
gikan melalui media sosial pegawai RSUD

RAA Soewondo Pati. Peneliti memberikan penjelasan mengenai petunjuk pengisiannya untuk mempermudah responden mengambil keputusan.

Populasi dalam penelitian ini adalah seluruh karyawan RSUD RAA Soewondo Pati. Penetapan Sampel menggunakan metode Purposive Sampling dengan judgement sampling. Sampel ini ditentukan berdasarkan kriteria yaitu tenaga medis dan non medis RSUD RAA Soewondo Pati berjumlah 523 orang dan memiliki masa kerja lebih dari 1 tahun karena dalam melakukan penilaian lebih memahami sistem pemberian insentif, pelatihan maupun pengendalian intern rumah sakit.

Ukuran sampel yang diambil dalam penelitian ini menggunakan metode slovin (Selvilla et.al, 2007)

$$
n=\frac{N}{N(e)^{2}}+1
$$

Dimana

$\mathrm{n}=$ jumlah sampel

$\mathrm{N}=$ jumlah populasi

$\mathrm{e}=$ Batas toleransi kesalahan (error tolerance), nilai presisi $95 \%$ atau sig $=$ 0,05

Berdasarkan kiteria di atas didapatkan data sebanyak 523 karyawan rumah sakit baik tenaga medis maupun non medis sehingga dengan menggunakan metode slovin (batas tolerance 0.05) maka jumlah sampel yang digunakan dalam penelitian ini adalah sebanyak 231. Teknik pengolahan data dalam penelitian ini menggunakan alat analisis SPSS dengan analisis regresi linier.

\section{HASIL DAN PEMBAHASAN}

Penelitian ini dilakukan dengan menggunakan metode Purposive Sampling dengan judgement sampling yaitu tipe pemilihan sampel secara tidak acak yang informasinya diperoleh dengan menggunakan pertimbangan tertentu (Sekaran, 1992). Berdasarkan kriteria tersebut, maka dapat dijelaskan hasil penyebaran kuesioner pada tabel dibawah ini.

Tabel 1. Data Penyebaran dan Tingkat Pengembalian Kuesioner

\begin{tabular}{|l|l|l|}
\hline & Jumlah \\
\hline Kuesioner yang dibagikan & 235 & 235 \\
\hline Kuesioner yang tidak direspon & $(185)$ & \\
\hline Kuesioner yang direspon & & 50 \\
\hline $\begin{array}{l}\text { Kuesioner yang rusak atau } \\
\text { tidak dapat digunakan }\end{array}$ & $(0)$ & 50 \\
\hline $\begin{array}{l}\text { Kuesioner yang dapat } \\
\text { digunakan / diolah }\end{array}$ & $21,28 \%$ \\
\hline $\begin{array}{l}\text { Tingkat pengembalian } \\
\text { kuesioner }\end{array}$ & \\
\hline
\end{tabular}

\section{HASIL}

Pada penelitian ini dilakukan uji statistik deskriptif yang bertujuan untuk memberikan deskripsi suatu data yang dilihat dari rata-rata (mean), standar deviasi (standard deviation) dan maksimumminimum. Adapun hasil uji statistik deskriptif dapat dilihat pada tabel 2, sebagai berikut. 
Tabel 2. Hasil Statistik Deskriptif

\begin{tabular}{|l|l|l|l|l|l|l|l|}
\hline Variabel Penelitian & N & $\begin{array}{l}\text { Rentang } \\
\text { Teoritis }\end{array}$ & Mean & $\begin{array}{l}\text { Rentang } \\
\text { Aktual }\end{array}$ & Mean & Std.Dev \\
\hline Kinerja & 50 & $6-30$ & 18 & $19-30$ & 27,76 & 2,199 \\
\hline Insentif & 50 & $9-45$ & 27 & $20-45$ & 36,56 & 5,365 \\
\hline Pelatihan & 50 & $5-25$ & 15 & $5-25$ & 20.50 & 3,940 \\
\hline Pengendalian Intern & 50 & $10-50$ & 30 & $30-50$ & 42,36 & 3,901 \\
\hline
\end{tabular}

Sumber: Data Primer diolah, 2020

Berdasarkan tabel 2 statistik deskriptif di atas variabel kinerja karyawan memiliki kisaran teoritis 6 - 30 dengan mean 18. Pada kisaran aktual $19 \quad-30$ dengan nilai rata-rata (mean) 25,76 dan standar deviasi sebesar 2,199. Dengan nilai rata-rata (mean) sesungguhnya sebesar 25,76 yang lebih besar dari mean teoritis, hal ini menunjukkan bahwa kinerja responden adalah tinggi. Nilai rata-rata aktual yang lebih besar dari standar deviasi maka jawaban tentang kinerja antara satu responden dengan lainnya tidak jauh berbeda.

Hasil statistik deskriptif untuk variabel insentif memiliki kisaran teoritis 9-45 dengan mean 27. Pada kisaran aktual antara 20-45 dengan nilai rata-rata (mean) 36,56 dan standar deviasi sebesar 5,365. Dengan nilai rata-rata (mean) sesungguhnya sebesar 36,56 lebih besar dari rata-rata teoritis, hal ini menunjukkan bahwa insentif yang diberikan adalah tinggi. Nilai rata-rata aktual yang lebih besar dari standar deviasi maka jawaban tentang in- sentif antara satu responden dengan lainnya tidak jauh berbeda.

Hasil statistik deskriptif untuk variabel pelatihan memiliki kisaran teoritis 5 25 dengan mean 15. Pada kisaran aktual 5 -25 dengan nilai rata-rata (mean) 20,50 dan standar deviasi sebesar 3,939. Dengan nilai rata-rata (mean) sesungguhnya sebesar 20,50 lebih besar dari rata-rata teoritis, hal ini menunjukkan bahwa pelatihan kerja yang diberikan sudah sesuai dalam meningkatkan kinerja. Nilai rata-rata aktual yang lebih besar dari standar deviasi maka jawaban tentang pelatihan kerja antara satu responden dengan lainnya tidak jauh berbeda

Pengendalian Intern memiliki kisaran teoritis 10- 50 dengan mean sebesar 30. Pada kisaran aktual 30-50 dengan nilai rata-rata (mean) 42,36 dan standar deviasi sebesar 3,901. Dengan nilai rata-rata (mean) sesungguhnya sebesar 42,36 lebih besar dari rata-rata teoritis, hal ini menunjukkan bahwa pengendalian intern yang dimiliki adalah tinggi. Nilai rata-rata actual lebih besar dari standar deviasi maka jawaban tentang pengendalian intern antara satu responden dengan lainnya tidak jauh berbeda.

\section{Uji Validitas}

Uji validitas bertujuan untuk mengukur ketepatan instrumen yang digunakan 
dalam suatu penelitian. Berdasarkan hasil pengujian validitas setiap item pertanyaan dari variabel insentif, pelatihan kerja, pengendalian intern dan kinerja karyawan dengan menggunakan bantuan program SPSS, diperoleh hasil $r$ hitung lebih besar dari pada $r$ tabel ( $\mathrm{r}$ hitung $>0,2787$ ), jadi variabel tersebut dapat dikatakan valid atau data akurat.

\section{Uji Reabilitas}

Uji reliabilitas insentif, pelatihan, dan pengendalian kerja terhadap kinerja karyawan memberikan hasil sebagai berikut:

Tabel 3. Hasil Uji Reliabilitas

\begin{tabular}{|l|l|l|l|l|}
\hline No & Vaxiabel & $\begin{array}{l}\text { Cronbach } \\
\text { Alpha }\end{array}$ & $\begin{array}{l}\text { Alpha } \\
\text { Standar }\end{array}$ & Ketex \\
\hline 1 & Insentif & 0,766 & 0,6 & Reliab \\
\hline 2 & Relatihan Kerja & 0,822 & 0,6 & Reliab \\
\hline 3 & Rengendalian Intern & 0,765 & 0,6 & Reliab \\
\hline 4 & Kineria Karyawan & 0,757 & 0,6 & Reliab \\
\hline
\end{tabular}

Sumber: Data Primer diolah, 2020

Berdasarkan hasil pengujian reliabilitas diatas, diketahui angka cronbach alpha masing-masing variabel insentif, pelatihan kerja, pengendalian intern dan kinerja karyawan lebih besar dari nilai minimal cronbach alpha 0,6. Oleh karena itu dapat disimpulkan bahwa insrumen penelitian yang digunakan untuk mengukur variabel kinerja karyawan dapat dikatakan reliabel atau handal.

\section{Uji Asumsi Klasik}

Uji asumsi klasik adalah memberikan kepastian bahwa persamaan reg- resi yang didapatkan memiliki ketepatan dan estimasi tidak bias dan konsisten. Uji asumsi klasik yang terdiri dari uji normalitas, uji autokorelasi, uji multikolinieritas, uji heteroskedastisitas. Hasil pengujian asumsi klasik disajikan pada tabel 4 di bawah ini:

Tabel 4. Hasil Uji Asumsi Klasik

\begin{tabular}{|c|c|c|c|c|c|}
\hline \multirow[t]{2}{*}{ Parameter } & $\begin{array}{l}\text { Uji } \\
\text { Normal }\end{array}$ & \multicolumn{2}{|c|}{$\begin{array}{l}\text { Uji } \\
\text { Multikolonieritas }\end{array}$} & \multirow[t]{2}{*}{$\begin{array}{l}\text { Uji } \\
\text { Heteroskedastisitas }\end{array}$} & $\begin{array}{l}\text { Uji } \\
\text { Autokorelasi }\end{array}$ \\
\hline & $\begin{array}{l}\text { Asymp.sig. } \\
\text { (2-tailed) }\end{array}$ & Tolerance & VIF & & $\begin{array}{l}\text { Asymp.sig. } \\
\text { (2-tailed) }\end{array}$ \\
\hline Insentif & 0,195 & 0,617 & 1,620 & \multirow{3}{*}{$\begin{array}{c}\text { Tidak Terjadi } \\
\text { Heteroskedastisitas }\end{array}$} & 0,775 \\
\hline Pelatihan & & & & & \\
\hline $\begin{array}{l}\text { Pengendalian } \\
\text { Intern }\end{array}$ & & & & & \\
\hline
\end{tabular}

Sumber: Data Primer Diolah, 2020

Berdasarkan tabel diatas maka model penelitian telah memenuhi asumsi klasik yang terdiri dari uji normalitas, uji multikolinieritas dan uji heterokedastisitas yang berarti bahwa model layak digunakan untuk memprediksi.

Uji normalitas dilihat dari Sig (2tailed) sebesar 0,195 lebih besar dari tingkat signifikansi (level of significant) yaitu sebesar 0,05 (5\%). Hasil pengujian ini menunjukkan bahwa data yang dianalisis berdistribusi normal. Uji Multikolinearitas dapat dilihat dari nilai tolerance masing-masing variabel bebas lebih besar dari 0,10 (10\%), dari ketiga variabel bebas diatas memiliki nilai tolerance lebih dari 0,10 dan nilai VIF Kurang dari 10 
yang berarti variabel bebas tidak saling berkorelasi secara signifikan. Hasil penelitian menunjukkan bahwa tidak terjadi multikolinearitas.

Uji hetrokedastisitas menunjukkan bahwa titik-titik tidak membentuk pola yang jelas, serta titik-titik juga menyebar di atas dan di bawah angka 0 pada sumbu Y. Hasil pengujian ini menunjukkan bahwa model regresi yang ada terbebas dari asumsi heteroskedastisitas. Untuk uji autokorelasi dapat dideteksi dengan melihat uji run test diketahui nilai Asymp. Sig (2-tailed) sebesar 0,775 lebih besar >0,05, maka dapat disimpulkan bahwa tidak terdapat gejala atau masalah autokorelasi. Dengan demikian, masalah autokorelasi tidak dapat terselesaikan dengan durbin Watson dapat teratasi melalui uji run test sehingga analisis regresi linier dapat dilanjutkan.

Hasil uji penelitian hipotesis dengan teknik analisis data yang digunakan adalah analisis regresi linear berganda dapat ditunjukkan pada tabel berikut ini:

\section{Tabel 5 . Hasil Uji Hipotesis}

\begin{tabular}{|c|c|c|c|c|c|}
\hline \multirow[t]{2}{*}{ Uji Statistik t } & \multicolumn{2}{|c|}{$\begin{array}{l}\text { Unstandardized } \\
\text { Coefficinets }\end{array}$} & \multicolumn{2}{|c|}{$\begin{array}{l}\text { Standardized } \\
\text { Coefficients }\end{array}$} & \multirow[b]{2}{*}{ Sig } \\
\hline & B & Std.Error & Beta & $\mathbf{T}$ & \\
\hline Constant & 8.778 & 2.720 & & 3.227 & .002 \\
\hline Insentif & 0.41 & 056 & .099 & .728 & .470 \\
\hline Pelatihan & -.021 & .077 & -038 & -277 & .783 \\
\hline Pengendalian Intern & .376 & .065 & 667 & 5.826 & .000 \\
\hline \multicolumn{6}{|l|}{ Uji Statistik F } \\
\hline Nilai & \multirow{2}{*}{\multicolumn{2}{|c|}{$\begin{array}{l}13.782 \\
.000^{\mathrm{a}}\end{array}$}} & & & \\
\hline Sig & & & & & \\
\hline \multicolumn{6}{|c|}{ Uji Koefisien Determinasi } \\
\hline R Square & \multicolumn{2}{|c|}{.473} & & & \\
\hline Adjusted R Square & \multicolumn{2}{|l|}{.439} & & & \\
\hline
\end{tabular}

Dependent Variable: Kinerja

Sumber:Data Primer diolah,2020

Dari hasil uji analisis pada tabel 5 tersebut, maka dapat dijelaskan persamaan regresi sebagai berikut:

$Y=8,778+0,041_{X 1}-0,0211_{X 2}+$

$0,376_{X 3}+e$

\section{PEMBAHASAN}

Penelitian ini memiliki 3 variabel independen yaitu insentif, pelatihan dan pe- ngendalian intern dan variabel dependen adalah kinerja karyawan. Berdasarkan table 5 diatas, dapat dijelaskan hasil analisis sebagai berikut.

\section{Uji Statsitistik t}

Pengaruh Pemberian Insentif Terhadap Kinerja Karyawan. 
Hipotesis pertama (H1) menyatakan bahwa insentif berpengaruh signifikan terhadap kinerja karywan. Berdasarkan hasil pengujian regresi berganda, probabilitas signifikansi sebesar 0,470>0,05. Oleh karena probabilitas signifikan lebih besar dari 0,05, maka variabel insentif tidak berpengaruh signifikan terhadap kinerja karyawan atau hipotesis pertama (H1) ditolak. Hal ini menunjukkan bahwa pemberian insentif yang diberikan oleh RSUD RAA Soewondo pati tidak secara efektif dapat meningkatkan kinerja dikarenakan banyak faktor yang dapat mempengaruhi salah satunya adalah banyaknya keluhan karyawan bahwa pemberian insentif yang sering terlambat diberikan.

Penelitian yang sama juga ditunjukkan oleh Ardiani, Astrid dan Rini Nugraheni (2015), hasil penelitian memberikan bukti empiris bahwa pemberian insentif tidak berpengaruh positif signifikan terhadap kinerja karyawan. Hal ini berarti bahwa pemberian insentif tidak selalu dapat memberikan pengaruh pada kinerja karyawan. Konsisten dengan hasil penelitian yang dilakukan oleh Dewitha. Audya, Nur dan Santi (2017), hasil penelitian menunjukkan bahwa insentif tidak berpengaruh signifikan terhadap kinerja karyawan. Hal ini disebabkan masih terdapat beberapa pegawai yang tidak puas pada sistem pemberian insentif yang diberikan.

\section{Pengaruh Pelatihan Kerja Terhadap Kinerja Karyawan.}

Hipotesis kedua (H2) menyatakan bahwa pelatihan berpengaruh signifikan terhadap kinerja karyawan. Berdasarkan hasil pengujian regresi berganda, probabilitas signifikansi sebesar 0,783 >0,05. Probabilitas signifikan lebih kecil dari 0,05, maka variabel pelatihan kerja tidak berpengaruh signifikan terhadap kinerja karyawan atau hipotesis kedua $(\mathrm{H} 2)$ ditolak. Hasil tersebut menunjukkan bahwa pelatihan kerja yang diberikan kepada karyawan RSUD RAA Soewondo Pati tidak memberikan dampak dalam meningkatkan kinerjanya. Dapat disimpulkan bahwa pelatihan yang baik akan dapat meningkatkan kinerja, namun metode pelatihan dan materi yang diberikan tidak sesuai dalam pelaksanaan pelatihan akan dapat menurunkan kinerja karyawan.

Penelitian yang sama juga dilakukan oleh Ningsi, Ayu C, Taher dan Hamidah (2015), hasil penelitian menunjukkan bahwa pelatihan kerja tidak berpengaruh signifikan terhadap kinerja karyawan. Konsisten dengan penelitian yang dilakukan oleh Pakpahan, Saputra E, Siswidiyanto dan Sukanto (2014), hasil penelitian menunjukkan bahwa pelatihan kerja tidak berpengaruh signifikan terhadap kinerja karyawan. Penelitian juga dilakukan oleh Hok.Tjoen.T, Aida dan Sadikin 
(2015), hasil penelitian memberikan bukti empiris bahwa Pelatihan tidak berpengaruh nyata terhadap kinerja karyawan, Hal ini karena proses pelatihan mulai dari perencanaan kebutuhan pelatihan, perancangan program pelatihan, pelaksanaan pelatihan dan penilaian pelatihan belum dilaksanakan secara baik.

\section{Pengaruh Pengendalian Intern Terha- dap Kinerja Karyawan.}

Hipotesis ketiga (H3) menyatakan bahwa pengendalian intern berpengaruh signifikan terhadap kinerja karyawan. Berdasarkan hasil pengujian regresi berganda, probabilitas signifikansi sebesar 0,000< 0,05 . Oleh karena probabilitas signifikan lebih kecil dari 0,05, maka variabel pengendalian intern berpengaruh signifikan terhadap kinerja karyawan atau hipotesis ketiga (H3) diterima. Hal ini menunjukkan bahwa kelima komponen pengendalian intern yang dimiliki oleh RSUD RAA Soewondo Pati dapat dilaksanakan dengan baik. Pengendalian yang diterapkan oleh manajemen rumah sakit tersebut berjalan efektif dan dapat memberikan dampak dalam meningkatkan kinerja karyawan.

Penelitian yang sama juga dilakukan oleh Shoimah, Siti, lailis (2015), hasil penelitian menunjukkan bahwa lima komponen pengendalian yaitu lingkungan pe- ngendalian, penilaian resiko, aktivitas pengendalian, informasi dan komunikasi, pemantauan berpengaruh positif signifikan terhadap kinerja karyawan. Konsisten dengan penelitian yang dilakukan oleh Tresnawati, Rina (2012), hasil penelitian memberikan bukti empiris bahwa pengendalian intern berpengaruh positif signifikan terhadap kinerja karyawan. Penelitian yang dilakukan oleh Maharani, Farisa.L, Septarina dan Siti (2015), hasil menunjukan bahwa pengendalian intern berpengaruh positif signifikan terhadap kinerja karyawan. Dapat disimpulkan bahwa kesadaran karyawan akan pelaksanaan pengendalian intern didalam organisasi tempat mereka bekerja cukup baik. Semakin karyawan memahami lingkungan pengendalian yang ada dilingkungan kerjanya dapat dipastikan kinerja karyawan akan mendukung tercapainya tujuan organisasi.

\section{Uji Statistik F}

Pengaruh insentif, Pelatihan Kerja dan Pengendalian Intern Secara BersamaSama Terhadap Kinerja Karyawan.

Hipotesis keempat (H4) menyatakan bahwa pemberian insentif, pelatihan kerja dan pengendalian intern secara bersama-sama berpengaruh terhadap kinerja karyawan. Berdasarkan hasil pengujian regresi berganda dilihat dari uji f, probabi- 
litas memiliki signifikansi sebesar $0,000^{\mathrm{a}}<$ 0,05 . Oleh karena probabilitas signifikan lebih kecil dari 0,05, maka variabel pengendalian intern berpengaruh signifikan terhadap kinerja karyawan atau hipotesis ketiga (H4) diterima. Hal ini menunjukkan bahwa pemberian insentif, pelatihan kerja dan pengendalian intern secara bersama-sama berpengaruh terhadap kinerja karyawan.

Penelitian yang sama juga dilakukan oleh Rizki, Amanda B, Saryadi dan Reni (2013), Hasil menunjukkan bahwa pemberian insentif dan pelatihan kerja secara bersama-sama berpengaruh signifikan terhadap kinerja karyawan. Namun insentif menjadi faktor yang paling berpengauh terhadap kinerja karyawan. Konsisten dengan penelitian yang dilakukan oleh Fitriani, Septi (2017), hasil menunjukkan bahwa pemberian insentif dan pengendalian intern berpengaruh signifikan secara simultan terhadap kinerja karyawan. Dapat diartikan bahwa adanya pemberian insentif, pelatihan kerja dan pengendalian intern yang baik akan dapat berdampak positif terhadap meningkatnya kinerja karyawan.

\section{Koefisien Determinasi $\left(\mathbf{R}^{2}\right)$}

Nilai koefisien determinasi berfungsi untuk menjelaskan seberapa tinggi kemampuan model dalam memberikan variasi variabel dependen. Hasil output
SPSS 16.0 untuk koefisien determinasi dapat dilihat dari tabel 6 berikut ini.

Tabel 6 Koefisien Determinasi

\begin{tabular}{ccccc}
\hline Model & $\begin{array}{c}\text { R } \\
\text { Square }\end{array}$ & R & \multicolumn{2}{c}{$\begin{array}{c}\text { Adjusted Std. Error Of } \\
\text { The Estimate }\end{array}$} \\
\hline 1 & $0.688^{\mathrm{a}}$ & 0.473 & 0.439 & 1.648
\end{tabular}

Sumber: Data Primer diolah, 2020

Berdasarkan tabel diatas diperoleh nilai adjusted $\mathrm{R}$ square sebesar 0,439 . Berarti variabel independen yang terdiri dari variabel insentif, pelatihan kerja dan pengendalian intern memberikan kontribusi sebesar $43,9 \%$. Sedangkan sisanya $57,1 \%$ dijelaskan oleh variabel lain di luar model. Nilai standar error of the estimate sebesar 1,648 hal ini mengindikasikan bahwa semakin kecil nilai ini, maka semakin tepat model memprediksi variabel dependen (Y).

\section{KESIMPULAN DAN SARAN}

Berdasarkan pembahasan pada penelitian ini maka dapat ditarik kesimpulan hasil uji secara parsial menunjukkan bahwa insentif tidak berpengaruh signifykan terhadap kinerja karyawan. Pelatihan kerja tidak berpengaruh signifikan terhadap kinerja karyawan. Untuk hasil uji secara simultan (bersama-sama) menunjukkan bahwa pengendalian intern berpengaruh signifikan terhadap kinerja karyawan. Insentif, pelatihan kerja dan pengendalian intern secara bersama-sama berpengaruh signifikan terhadap kinerja karya- 
wan. Implikasi dari penelitian ini diharapkan dapat dijadikan sebagai bahan pertimbangan organisasi dalam meningkatkan kinerja karyawan dengan memperhatikan pemberian insentif, pelatihan kerja dan pengendalian intern.

Saran dari hasil penelitian ini yang dapat peneliti ajukan adalah sebaiknya RSUD RAA Soewondo Pati agar lebih memperhatikan dalam pemberian insentif kepada karyawan baik dari segi ketepatan waktu maupun kesesuaian insentif dengan kinerja karyawan. Hal tersebut dapat dilihat bahwa insentif tidak berpengaruh terhadap kinerja. Pelatihan kerja juga perlu ditingkatkan dalam menunjang kualitas kerja karyawan.

Untuk pengendalian intern pada rumah sakit tersebut sudah bagus kedepannya untuk lebih ditingkatkan lagi. Saran untuk peneliti selanjutnya bisa dilaksanakan dengan ruang lingkup yang lebih luas sehingga dapat menghasilkan penelitian yang lebih baik. Peneliti selanjutnya dapat menambah beberapa variabel seperti gaya kepemimpinan, disiplin kerja dan faktor lain yang dapat memengaruhi kinerja

\section{DAFTAR PUSTAKA}

Al-Mzary, Al-rifai, Al- Momany. 2015. Training And Its Impact On The Performance Of Employee At Jordanian Universities From The Perpective Of Employees : The Case Of Yarmouk University. Journal of
Education and Practice. Vol.6, No.32.

Al-Omari, A., Al-Momani, N., Omar, M., Jordanian, R., Bureau, H., \& Bank, A. 2017. The impact of incentives on the performance of employees in public sector : Case study in Ministry of labor. 9(9),119-130.

Al-Tamimi, Khaled. 2018. Impact Of Financial On Performance Of Employees In Jordanian Commercial Banks And Its Reflections On Jordanian Economy: A Field Study. Department of Administrative and Financial Sciences, Irbid University College, Al-Balqa Applied University- Jordan. Vol.7.Issue.1.

Ardiani, Astrid dan Rini Nugraheni. 2015. Analisis Pengaruh Pemberian Insentif Dan Lingkungan Kerja Non Fisik Terhadap Motivasi Kerja Dan Dampaknya Pada Kinerja Karyawan. (Studi Pada BRI Kantor Cabang Pattimura). Jurnal Manajemen. Fakultas Ekonomika Dan Bisnis. Univerisitas Diponegoro Semarang. Vol.4. No.4.

Dewintha, Audya, Nur dan Santi. 2017. Pengaruh Pemberian Insentif Dan Motivasi Terhadap Kinerja Pegawai Di Kantor Camat Samarinda Utara. Jurnal Administrasi. Vol.5. No.3.

Fitriani, Septi. 2017. Pengaruh Sistem Pngendalian Intern Dan Tunjangan Kinerja Terhadap Kinerja Pegawai Kantor Pertanahan Kabupaten/ Kota Pada Provinsi Lampung. Tesis. Fakultas Ekonomi Dan Bisnis. Universitas Lampung. Bamdar Lampung.

Ghozali, Imam. 2011. Aplikasi Analisis Multivariate dengan Program IBM SPSS 19. Cetakan V, Semarang: Badan Penerbit Universitas Diponegoro. 
Gamage, M. W. K., Hewage, C., \& Pathirana, K. D. (2018). Effect of cognitive and executive functions on perception of quality of life of cognitively normal elderly people dwelling in residential aged care facilities in Sri Lanka. BMC Geriatrics, 18(1), 1-10. https://doi.org/10.1186/s12877-0180937-6.

Haryati, Ari. R. 2019.Analisis Pelaksanaan Program Pelatihan Dan Pengembangan Karyawan: Studi Kasus Pada PT Visi Sukses Bersama Jakarta. Jurnal Administrasi Perkantoran. Universitas Bina Sarana Informatika.Vol.3.No.1.

Hidayat, Irwana, Erry dan Sri. 2014. Pengaruh Pemberian Insentif dan Pelatihan Kerja Terhadap Kinerja Karyawan Front Office Department Di the Trans Luxury Hotel Bandung. Jurnal Manajemen Resort \& Leisure. Vol. 11, No. 2.

Hok.Tjoen.T, Aida dan Sadikin. 2015. Pengaruh Pelatihan Dan Motivasi Terhadap Kinerja Karyawan Kasus Perusahaan Distributor Alat Berat. Management and Business, Postgraduate School of Bogor Agricultural University (IPB). Vol.16.No.2.

Kurniawan, I. A., Murdiati, S., \& Subroto, S. (2019). Pengaruh Kebutuhan Aktualisasi Diri, Penghargaan dan Komitmen Kerja terhadap Kinerja Karyawan di SMK 1 Kedungwuni Kab. Pekalongan. Permana : Jurnal Perpajakan, Manajemen, Dan Akuntansi, 11(2), 158-172. https://doi.org/10.24905/permana.v1 $1 \mathrm{i} 2.44$

Maharani, Farisa.L, Septarina dan Siti. 2015. Pengaruh Pengendalian Internal Terhadap Kinerja Karyawan Pada Divisi Pelayanan Medis Rumah
Sakit Jember Klinik. Jurnal Akuntansi Universitas Jember. Vol.13. No.2.

Mayasari, Mega dan Rani Hangga. I. 2017. Pengaruh Penilaian Kinerja Terhadap Kinerja Karyawan Dengan Motivasi Sebagai Variabel Moderasi.. Jurusan Manajemen Bisnis. Politeknik Negeri Batam.

Meutia, Rahmi (2015). Pengaruh Pendidikan dan Pelatihan serta Insentif terhadap Kinerja Karyawan pada Kantor Pusat PT Perkebunan Nusantara I (Persero) Langsa. Jurnal Manajemen. Universitas Samudra. Vol.4. No.1.Mondy R Wayne. 2008. Manajemen Sumber Daya Manusia . Jakarta: Erlangga.

Nassazi, Aidah. 2013. Effects of Training on Employee Performance. Evidence from Uganda. Business Economics and Tourism. University of Applied Sciences.

Ningsi, Ayu C, Taher dan Hamidah. 2015. Pengaruh Pelatihan Dan Promosi Terhadap Motivasi Dan Kinerja Karyawan. (Studi Pada Karyawan PT. PLN (Persero) Area Kendari). Jurnal Administrasi Publik. Vol.5. No.1..

Olufanmilayo, Abosede, Adedeji. 2018. Effect of Internal Control System on Employee Performance of SmallScale Manufacturing Enterprises in Ondo State, Nigeria. Journal Human Resource Research. ISSN 1948-5441 2018, Vol. 2, No. 1

Panggabean.S.2002. Manajemen Sumber Daya Manusia. Bogor: Ghalia Indonesia.

Peraturan Bupati Pati Nomor 74 Tahun 2018 Tentang Renumerasi Pada Rumah Sakit Umum Daerah RAA Soewondo Pati. 
Rizki, Amanda Bounita. Saryadi dan Reni. 2013. Pengaruh Pelatihan Dan Insentif Terhadap Kinerja Karyawan Bagian Marketing PT. Nasmoco Gombel Semarang. Jurnal Administrasi Dan Bisnis. Universitas Diponegoro.

Sekaran, Uma. 2011. Research Methods For Bussiness. Jakarta: Salemba Empat.

Sharma, S., \& Taneja, M. (2018). The effect of training on employee performance. International Journal of Recent Technology and Engineering, 7(4), 6-13. https://doi.org/10.31104/jsab.v2i2.49

Shoimah, Lailis, Siti. 2015. Pengaruh Pengendalian Internal Terhadap Kinerja Karyawan Hotel di Kabupaten Jember. Jurnal Akuntansi, Fakultas Ekonomi. Universitas Jember.

Sugiarto, M., Waskito, J., \& Jalil, M. (2019). Pengaruh Implementasi Knowledge Management dan Stres Kerja Terhadap Kinerja Karyawan pada PT. Asaputex Jaya Kota Tegal. Permana : Jurnal Perpajakan, Manajemen, Dan Akuntansi, 11(2), 144-157. https://doi.org/10.24905/permana.v1 $1 \mathrm{i} 2.45$

Stajkovic, A. D. (2003). Behavioral Management and Task Performance in Organizations: Conceptual Alternative Models.

Taradipa, P. S. 2015. Pengaruh Pengendalian Intern Terhadap Kinerja Karyawan studi kasus pada PT.Bank Panin Tbk cabang Kendari. Jurnal Akuntansi, 1(1), 2-13.

Tresnawati, Rina. 2012. Pengaruh Efektifitas Pengendalian Intern Terhadap Kinerja Instansi
Pemerintah Di Dinas Pendapatan Daerah Kota Bandung. Universitas Widyatama.

Weerasinghe, Gamini. 2017. Financial Incentive Impact On Employee Motivation: A Study In University Of Sri Jayewardennepura Sri Lanka. Departement Of Economics. Vol. 7 I 